\title{
Nepal and COVID-19: A strange case and the Dilemma
}

\author{
Amit Thapa MS, MCh, IFAANS \\ Professor and Head, Department of Neurological Surgery \\ Kathmandu Medical College Teaching Hospital (KMCTH) \\ Sinamangal, Kathmandu, Nepal \\ ORCID iD: https://orcid.org/0000-0003-1896-3115
}

\author{
Address for correspondence: \\ Professor Amit Thapa \\ Head of Department, Department of Neurological Surgery \\ Kathmandu Medical College Teaching Hospital (KMCTH) \\ Sinamangal, Kathmandu, Nepal \\ E-mail: dramitthapa@yahoo.com \\ Contact number: +9779851177995
}

Date of submission: $30^{\text {th }}$ March 2020 (Updated: $19^{\text {th }}$ April 2020)

Date of acceptance: $20^{\text {th }}$ April 2020

\section{Preface}

OVID-19 caused by SARS-CoV-2 started as an outbreak in Wuhan, China in December $2019 .{ }^{1}$

Despite strict measures put up by China, its silent but highly contagious nature led to widespread dissemination which made World Health Organization (WHO) declare it as a global pandemic on 11 March $2020 .{ }^{2}$ With 152,523 people dying among 2,347,060 affected in 213 countries and territories due to the disease, nations are fighting to "flatten the curve of epidemic. ${ }^{3}$

\section{Curious Case of Nepal}

The situation in Nepal has been rather strange. Due to its geographical proximity to China and porous borders, WHO quickly declared it a high-risk country for COVID-19, however, only few cases had been reported till date with no record of local transmission (except for one with direct contact) even after testing 8081 samples. ${ }^{4}$ It appears as if Nepal has been able to keep the pandemic in early phase for this long! This occurred despite a late and half-hearted attempt to restrict entry of visitors and limited screening (for fever only) of the immigrants both at the international airport and borders. On January 26, the first case was reported (in a 31 years old student who had returned from Wuhan on January 5) when the epidemic was at its peak in neighboring China. The second case was diagnosed almost eight weeks later on March 23, and within four weeks 29 more cases were identified, all of

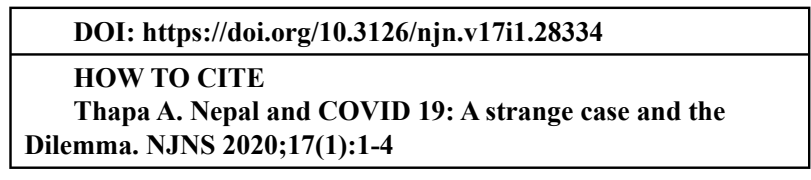

To access Nepal Journal of Neuroscience Archives, scan $Q R$ code:

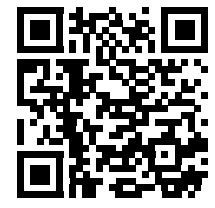

whom had come from abroad (however this time not from China) except for one, wife of one of the positive. ${ }^{1}$ Nepal seems to be untouched both by the initial surge in China and the later escalations in India and the world around, which sounds miraculous!

Hypothetically, this could be due to weakening of coronavirus (following genetic mutations), protection offered by mass vaccination with Bacillus CalmetteGuérin (BCG) vaccine, missing cases in population due to limited screening, false negative tests due to failure in processing of samples or poor contact tracing! 1,5

\section{Lockdown: is it an overkill?}

As the cases outside China started growing which has now superseded the numbers seen in China, Governments around the world are in a desperate situation. Though lockdown of infected cities and quarantine of patients seem to have worked in populations with massive infection (in phase 3), ${ }^{5,6,7}$ nations where only few cases have been reported yet, the logic of such strict measures seem like an overkill. Without adequate preparation, the financial implications are unimaginable and the hand-tomouth existential difficulties of daily wage earners is heart reckoning. Support is being offered but is too little and not uniformly distributed. ${ }^{1}$

The fear of infection spreading if not contained initially, resulting in massive unbearable pressure on health system was persuasive enough to enforce such 
tighter regulation. This helped avoid crowding of public places (limiting the risk of human to human spread) and kept medical systems free from usual load to absorb any sudden surge of COVID-19.,

The problem of such action besides administrative, is not only how to measure its success but also to decide when to release the lockdown as we do not know the "true" community prevalence of the disease.

The alternative would have been to strictly monitor every visitor coming inside Nepal with at least a fortnight of quarantine and test for SARS-CoV-2 infection. However, our initial failure to observe this measure rigorously has created an uncertainty that COVID-19 might have gone to phase 2 (in other clusters) or even phase 3 in rural or unmonitored areas. ${ }^{6,7}$ At present, this coupled with measures to identify and isolate cases remains our best bet to avoid the development of the epidemic. ${ }^{8}$ All hospitals and border immigration should religiously run "COVID-19 Screening/Fever Clinic" to screen every visitor and investigate if found symptomatic.

\section{The Dilemma}

Surrounded by all these confusion and panic, the doctors faced a dual problem of arranging a fight with the unknown as well as mitigating risk of being exposed. SARS-CoV-2 is highly infectious and can be transmitted even by asymptomatic people. ${ }^{8}$ Due to limited facility of testing (requiring bio-safety level-2 laboratories), not all patients could be tested for COVID-19. Handling patients without proper protective gear is a nightmare. ${ }^{8,9}$

Initially experts were not sure whether this virus could be airborne. However, later they did explain that during procedures involving drilling and irrigation of oral cavity, aerosols can be generated otherwise the spread is usually through droplets. ${ }^{2}$ The health facilities across Nepal had never used N95 masks till then. The news in the social media led to widespread frenzy and the market was soon sucked out of surgical masks, not to talk of N95. Even personal protective equipment (PPE), which were available in limited quantities were being black marketed.

With government-imposed lockdown, hospitals were being prepared for massive influx of COVID-19 patients, leaving usual health services in despair. But diseases like stroke, myocardial ischemia, diabetes, hypertension or cancers have nothing to do with coronavirus and these patients had to suffer. Doctors across various hospitals offered their personal contact numbers for the patients to call them and some even continued their hospital services though limited, to attend emergency situations. Hospitals across the country made PPE from locally available materials and restructured their working place to embrace the disaster.
The government had planned for plan $\mathrm{C}$ in the event of a mass epidemic but the plan A (containment) and plan $B$ (treatment of the infected) were not properly conducted due to lack of equipment and ambiguity of protocols. Hospitals - mostly private institutions (who were left out in plan A and plan B), prepared and coordinated their own plans with their limited resources on the basis of government directives which were vague and often impromptu, declared to counter some issues raised by social media.

\section{Any Roadmap?}

In this unusual scenario where not only epidemiological profile but also the strategies to contain and treatment are constantly changing, it is comprehensible why a single universal protocol is not applicable..$^{8,10,11,12}$ In the last 2 weeks, doubling time of positive cases in Nepal appears to be shortening and the situation demands for careful planning and execution at all levels. What remains clear from the recent resurgence of COVID-19 is

- It is going to take longer to contain the disease

- Infectivity rate and case fatality rate is far higher than in China (particularly in western societies)

- Mode of transmission is from human to human through droplets (or aerosols in selected situations)

- Vaccine and efficacious treatment are not going to be readily available soon (as trials to test safety and efficacy require time)

With these facts, what we can propose

- All health care workers (HCW) should join forces as a common team against COVID-19

- Measures should be enforced in phases and recommended individually for HCWs, hospitals, public and government (Table 1)

- Laboratories should be upgraded to allow investigation for COVID-19 (particularly near places identified to keep quarantined and isolated patients)

- Besides symptomatic people, testing for COVID-19 should also be offered to all patients being admitted to hospitals or undergoing surgery, HCW involved in patient care and all immigrants

- Government should either manufacture or procure PPE in sufficient quantities and limit the distribution to hospitals for their staff on clinical services or to families taking care of suspected or infected patients under home surveillance

- All neurosurgeons and other surgical specialties should stop operating on non-urgent cases or use bail out surgeries at present (to prevent consuming essential PPE and also avoid unnecessary exposures to crowd). Guidelines are being provided by societies and monitoring agencies. ${ }^{10,11,12,13}$ 


\begin{tabular}{|c|c|c|c|c|}
\hline Phase & $\begin{array}{l}\text { Epidemiological } \\
\text { control }\end{array}$ & $\begin{array}{c}\text { HCW and hospital } \\
\text { initiative }\end{array}$ & Public initiative & Government initiative \\
\hline $\begin{array}{l}\text { 1. (Imported): sporadic } \\
\text { cases travelling from } \\
\text { other countries }\end{array}$ & $\begin{array}{l}\text { - Containment } \\
\text { - Keep this phase } \\
\text { for long if } \\
\text { possible }\end{array}$ & - Fever Clinic & $\begin{array}{l}\text { - Hospital based } \\
\text { isolation of } \\
\text { symptomatic and } \\
\text { self-quarantine of } \\
\text { exposed } \\
\text { - Personal hygiene } \\
\text { measures }\end{array}$ & $\begin{array}{l}\text { - Active surveillance } \\
\text { - Strict immigration } \\
\text { - Screening of each } \\
\text { visitor with test for } \\
\text { SARS-CoV-2 }\end{array}$ \\
\hline $\begin{array}{l}\text { 2. (Local transmission } \\
\text { among contacts): when } \\
\text { imported case infects its } \\
\text { close contacts }\end{array}$ & $\begin{array}{l}\text { Keep this phase } \\
\text { for long if } \\
\text { possible }\end{array}$ & $\begin{array}{l}\text { - Besides above } \\
\text { - Manage Suspect } \\
\text { and positive cases } \\
\text { in isolation } \\
\text { - Use recommended } \\
\text { PPE } \\
\text { - Plan for isolation }\end{array}$ & $\begin{array}{l}\text { - At least } 14 \text { days } \\
\text { hospital-based } \\
\text { isolation of } \\
\text { symptomatic } \\
\text { and monitored } \\
\text { quarantine of } \\
\text { contacts/ exposed } \\
\text { - Social distancing }\end{array}$ & $\begin{array}{l}\text { - Closure of public } \\
\text { spaces where } \\
\text { crowding is expected } \\
\text { - Complete ban on all } \\
\text { travel }\end{array}$ \\
\hline $\begin{array}{l}\text { 3. (Community } \\
\text { transmission, epidemic): } \\
\text { when people who had } \\
\text { not come in contact } \\
\text { with positive patients } \\
\text { get infected. The faster } \\
\text { and more numbers get } \\
\text { infected, this phase } \\
\text { would accelerate } \\
\text { beyond control }\end{array}$ & $\begin{array}{l}\text { Keep this } \\
\text { phase as flat } \\
\text { as possible to } \\
\text { avoid resources } \\
\text { from being } \\
\text { overwhelmed }\end{array}$ & $\begin{array}{l}\text { - Besides above } \\
\text { - Hospital to run only } \\
\text { essential services } \\
\text { - Admit only positive } \\
\text { or suspects with } \\
\text { serious illness } \\
\text { - Quarantine of the } \\
\text { HCW taking care of } \\
\text { the patients }\end{array}$ & $\begin{array}{l}\text { - Hospital resource } \\
\text { would have been } \\
\text { exhausted } \\
\text { - Monitored home } \\
\text { isolation for } \\
\text { symptomatic and } \\
\text { self-quarantine for } \\
\text { contacts }\end{array}$ & $\begin{array}{l}\text { Total lockdown or } \\
\text { curfew in cities to } \\
\text { prevent people from } \\
\text { going out of their } \\
\text { homes } \\
\text { - Complete ban on } \\
\text { all travel inside or } \\
\text { outside country }\end{array}$ \\
\hline $\begin{array}{l}\text { 4. (Control): when no } \\
\text { more people remain } \\
\text { to be infected or the } \\
\text { disease is no more }\end{array}$ & $\begin{array}{l}\text { - Herd immunity } \\
\text { - Vaccination } \\
\text { (which is not } \\
\text { possible in near } \\
\text { future) }\end{array}$ & $\begin{array}{l}\text { - Continue fever } \\
\text { clinic till } 21 \text { days of } \\
\text { last case reported in } \\
\text { Nepal } \\
\text { - Start usual services } \\
\text { in phase manner } \\
\end{array}$ & $\begin{array}{l}\text { - Continue social } \\
\text { distancing and } \\
\text { personal hygiene }\end{array}$ & $\begin{array}{l}\text { - Strict Immigration } \\
\text { (allowing people } \\
\text { from countries } \\
\text { where last infection } \\
\text { is reported almost a } \\
\text { month back) }\end{array}$ \\
\hline
\end{tabular}

Table 1: Phase wise plan for health care workers, public and government

- Endo-nasal or trans-oral endoscopic procedures or procedures using drills which generate aerosols should be avoided or performed for emergency conditions with Category 1 PPE (according to Nepal Medical Council) $)^{9,11,12,13}$

- Elderlies and the patients who are immunosuppressed either due to their disease or because of immunosuppressive therapy should be particularly cared for and isolated from suspected and proven cases.

- HCW involved in service of COVID-19 positive patients should have facilities to stay inside hospital premises for 14 days

- Roster to change over every six hours (as PPE once gowned does not allow for eating food or even use mobile phone) and facilities to wash or decontaminate whole body after removing PPE should be made available. Handling of PPE is crucial. ${ }^{8,9}$

- Being a country dependent on tourism, Nepal is at risk of such contagious diseases in future and hence research facilities to identify and develop investigation kits and devise management modalities should be operationalized at the earliest

\section{Silver lining}

The silver lining of this epidemic has been universal attention to personal hygiene. None of the infected in Nepal has had serious illness or died. Warming temperatures may help control epidemic across the globe. Widespread lockdown has massively decreased pollution and personally most of us are having quality family times. 


\section{Summary}

Keeping the situation in Nepal in phase 2 for long would be the most cost-effective measure. It would not only give time to prepare for later spread till an effective treatment or vaccine is available but can also kill the disease by containing its spread, as eventually minor infections will get cured. Controlling COVID-19 is a national effort and contribution from each of us counts. For those of us on the frontline, if we remain healthy we can serve others without allowing ourselves to become a spreader, so all health care workers should take necessary precautions while delivering the humanity.

\section{References}

1. Wikipedia. 2020 coronavirus pandemic in Nepal [Internet]. [Cited 2020 Apr 1]. Available from: https://en.wikipedia.org/wiki/2020_coronavirus pandemic_in_Nepal

2. World Health Organization. Coronavirus disease 2019 (COVID-19) situation report-51 [Internet]. [Updated 2020 Mar 11; Cited 2020 April 1]. Available from: https://www.who.int/docs/default-source/ coronaviruse/situation-reports/20200311-sitrep-51covid-19.pdf?sfvrsn=1ba62e57_10

3. Financial Times. Coronavirus: free to read [Internet]. [Cited 2020 Apr 19]. Available from: https://www. ft.com/coronavirus-latest

4. Ministry of Health and Population, Nepal. COVID-19 [Internet]. [Cited 2020 Apr 19]. Available from: https://covid19.mohp.gov.np/

5. Anderson RM, Heesterbeek $\mathrm{H}$, Klinkenberg D, Hollingsworth TD. How will country-based mitigation measures influence the course of the COVID-19 epidemic? Lancet. 2020; 395(102280):931-4. https:// doi.org/10.1016/S0140-6736(20)30567-5

6. Siouxsie Wiles. The three phases of Covid-19 and how we can make it manageable [Internet].
Auckland: The Spinoff. [2020 Mar 9; cited 2020 Apr 1]. Available from: https://thespinoff.co.nz/ society/09-03-2020/the-three-phases-of-covid-19and-how-we-can-make-it-manageable/

7. CtoI News Desk. The four stages of COVID-19 explained. Connected to India [Internet]. [2020 Mar 18; Cited 2020 Apr 1]. Available from: https://www. connectedtoindia.com/the-four-stages-of-covid-19explained-7280.html

8. Handbook of COVID-19 Prevention and Treatment. The First Affiliated Hospital, Zhejiang University School of Medicine. Available from: https://wfns.org/WFNSData/Uploads/files/ Handbook-COVID19-GlobalMediXChange.pdf

9. Nepal Medical Council. Guidelines for use of personal protective equipment in relation to COVID-19 [Internet]. [2020 Mar 23; Cited 2020 Apr 1]. Available from: https://www.nmc.org.np

10. Nepal Medical Council. Professional Ethics During COVID-19 Pandemic [Internet]. [2020 Mar; Cited 2020 Apr 1]. Available from: https://www.nmc.org. $\mathrm{np}$

11. American Association of Neurosurgeons. COVID-19 Information Hub [Internet] Rolling Meadows, IL [Updated 2020 Mar 31; Cited 2020 Apr 1]. Available from: https://www.aans.org/COVID19-Update/COVID-19-Information-Hub

12. Congress of Neurological Surgeon. COVID-19 Neurosurgical Information Hub [Internet] Schaumburg, IL. [Cited 2020 Apr 1]. Available from: https://www.cns.org/covid-19

13. Zoia C, Bongetta D, Veiceschi P, Cenzato M, Meco FD, Locatelli D, Boeris D, Fontanella MM Neurosurgery during the COVID-19 pandemic: update from Lombardy, northern Italy [Internet]. Acta Neurochirurgica. 2020 Mar 28. https://doi. org/10.1007/s00701-020-04305-w. 